\title{
RESEARCH
}

\section{Negotiating French Social Citizenship in Early Twentieth-Century Letters to a Representative for the Rhône Department}

\author{
Karen Lauwers \\ ERC-funded CALLIOPE-project, University of Helsinki, Faculty of Arts, Department of Cultures, FI \\ karen.lauwers@helsinki.fi
}

Taking the distinction made by Patrick Hassenteufel between statutory and identity-based citizenship as a starting point, this article investigates expressions of the latter citizenship in early twentieth-century France. More specifically, this article focuses on how 'ordinary' men and women from a rural area in the Rhône department perceived their place in French republican society shortly before and during the First World War. The war years were a time when (claims to) social policies were continuously renegotiated, in relation to men and women's commitment to the Republic. Whether they had political voting rights or not, 'ordinary' citizens took part in these negotiation processes, yet in an informal (and therefore still underexposed) way, through written communication with a parliamentary representative (député).

Men and women who shared the same social background used similar rhetorical tactics in their requests for help, support, or a favour. Men's expressions of gratitude towards 'their' député could, however, entail a promise of a vote, whereas women were still not enfranchised. Though reminiscent of the image of a clientelist rural France at first sight, neither men's nor women's letters were characterised by mere trade-offs. Instead, they were increasingly revealing of how the letter-writers (re)imagined the notions attached to their citizenship. The connections between those concepts, such as (social) rights, duties, and knowledge (and the impact of the war on rhetorical constructions of these aspects of citizenship) are analyzed from the letter-writers' viewpoints. Focusing on such a micro-level allows for insights into the mutually educational nature of the common practice of sending letters to a French Third Republican parliamentary representative.

Keywords: Letter writing from below; social rights; political patronage; political communication; correspondence; First World War; French Third Republic 


\section{Negotiating French Social Citizenship in Early Twentieth-Century Letters to a Representative for the Rhône Department}

In his article on the relation between the welfare state and citizenship in nineteenth- and twentieth-century Western European societies, Patrick Hassenteufel (1996, 129-30) stresses the dual nature of the concept, which has a 'statutory' side and an 'identity-based' side. Citizenship as a statute, on the one hand, is a reciprocal relation, regulated by laws, between the state and the individual. Thus, it involves all duties that officially defined a citizen, as well as the rights that were granted to compensate for fulfilling these duties. Citizenship as an identity, on the other hand, refers to people's sense of belonging to society and therefore to the values they attached to it. The ability to imagine themselves as citizens required at least a certain notion of the 'official' definition of the concept (as a statute). Therefore, people's knowledge of their duties and rights formed an important link between both manifestations of the notion. At the same time - and together with their interest in politics - political knowledge can be seen as part of the citizens' duties.

In the case of France, 'good' citoyens were supposed to be aware of the 'republican project', and know their responsibilities as well as the way these would be rewarded. This did not imply passive acceptance of top-down created conditions for citizenship. In other words, identity-based citizenship cannot solely be interpreted in terms of what Hassenteufel (1996, 146) refers to as a 'collective identification, based on the community created by the nationstate.' It is important to acknowledge the individual experiences French people had with their (complete or incomplete) citizenship, as well as their agency to adjust or co-construct their French identities. During the war years, authorities had to promptly adapt and implement social policies in response to the rapidly changing reality. This not only challenged the knowledge-gathering process of men and women who tried to stay informed on the policies that could apply to them or their families. It also challenged them to discuss the effectiveness and equity of certain social measures and to negotiate their deservingness in their applications for state support.

Therefore, in this article, the connections between (social) rights, duties, and knowledge (and the impact of the First World War on rhetorical constructions of these aspects of citizenship) will be analyzed from the viewpoint of individual 'ordinary' French men and women. In this context, 'ordinary' refers to politically unorganised or rather informally or religiously organised citizens, irrespective of their social class or voting rights. The requests they sent to French parliamentarians (députés) were most often rooted in very personal (not rarely financial) issues, which they sought to overcome with the help of 'their' representative. Nonetheless, these sources also reveal early twentieth-century letter-writers' views of their place in society. Especially women, who were excluded from full statutory citizenship by the lack of female enfranchisement until 1944, seem to have felt the need to explain more explicitly why they contacted a député and why they thought they were deserving of his help. Hence, 'ordinary' citizens' letters to a French parliamentary representative are the sources par excellence for examining views of identity-based French citizenship that were not purely coming 'from below', nor just mirroring the official image from above but were interactively construed in negotiation with a political authority.

Such a study is particularly relevant for (early) twentieth-century France, because of how embedded communication between citizens and députés was in French Third Republican culture. France's weak intermediary structure (on the regional level) between the strong state and the individual was probably an important contributing factor to the approachability of the deputy. The very personal voting system, moreover, in combination with a remarkable lack of party discipline, could make citizens feel truly connected to the one member of the Chamber who represented their (entire but small) district (Beyen 2014, 23). Third Republican 
députés themselves cherished this ideal of 'proximity politics,' which was not only the case for the Parisian parliamentarians in Marnix Beyen's ongoing research $(2020,251)$ but also for deputies of rural districts. They often combined their representative role in parliament with a longstanding one as their department's representative of a specific canton, where they created opportunities for in-person interactions via walk-in consultations (permanences, audiences, or réceptions, cf. Lauwers 2019, 35-37, 53).

As Frédéric Monier (2007, 7-25) remarks, nineteenth-century republicans considered a system of favours and dependence to be a heritage from Ancien Régime societies, while in reality, the system remained. Even though it was denounced by several contemporaries during the Second and Third Republic, interventions were part of the députés job and became part of the regime. With the introduction of radical socialists in 1901 came the official sponsorship of favours. Deputies did not have to pay their 'clients' with their own money; there were public means for it, because 'the republican project' of equality of opportunities could offer a justification for such personal interventions. Pierre Rosanvallon $(1992,359)$ describes the pedagogical aspect of this project, situating its origins at the start of the Second Republic and the introduction of universal male suffrage (1848). Its main goal was to create a national (patriotic) spirit and to discipline the morals. Additionally, republicans hoped that the diffusion of a lay moral would reduce the political influence of the Church. This pedagogical project was not only meant to broaden support for and thus legitimacy of the Republic but also to directly educate its citizens towards being conscious political actors, Rosanvallon explains. Therefore, to understand the 'republican project' is to understand the Republic in general. Antoine Prost $(1997,215)$ equates the latter with universal (male) suffrage and with (male) citizens themselves, who through elections designated some peers to guide them. Republicanism was a liberal regime, based on law and elections, for which enlightened and virtuous citizens were required. In their active role as citizens of this democracy, members of the Republic had to internalise as well as propagate the republican principles of liberty, equality, and fraternity.

For this purpose, manuals for moral and civic education were introduced. They were supposed to teach children already at the elementary school level about the importance of the vote. These manuals idealised the vote as a pure expression of the individual's conscience and reason (Rosanvallon 1992, 363). By their nature, women could not be such rational citizens, it was believed. As (potential or actual) mothers, they were emotional instead of rational; thus, they were considered unfit for citizenship. Moreover, if they remained deeply religious, they could pose a potential threat to the ideal image of a republican citizen. To curb women's religious propensity, proper (lay) education and manuals were needed. (The law of 1882 on compulsory primary education considered civic instruction and literacy as important for girls as for boys. $)^{1}$ Consequently, the 'republican project' had to offer a paradoxical education to women. On the one hand, they had to be motivated to act as pillars of the Republic and learn about its values, to be able to encourage and assist their husbands and sons in their duties as citizens. On the other hand, women were not to be taught too much autonomy, for their place was still at home (Zancarini-Fournel 2005, 121). Nonetheless, according to Christine Bard $(2001,83)$, many French women saw themselves as citizens, even before their

\footnotetext{
${ }^{1}$ The first article of the new law established the mandatory focal points of primary education, among which 'moral and civic education; reading and writing; language and elements of French literature' were the first three, and thus possibly considered as the most important. In addition, 'some notions of justice and political economy' were to be taught to boys as well as girls. The only difference between both sexes embedded in this law, consisted of compulsory military exercise for boys, whereas girls had to learn needlework, cf. 'Loi sur l'enseignement primaire obligatoire', Journal officiel de la République française (JO). Documents parlementaires 14 (March 29, 1882): 1697-1698.
} 
full enfranchisement in 1944. Bard explains that the female form of the word 'citizen' (citoyenne) was already commonly used during the French Revolution, and later occurred in the discourse of twentieth-century socialists.

The way 'ordinary' women (especially in a more right-wing and rural context) perceived their French (republican) citizenship themselves, however, has escaped scrutiny, which is why their perspectives will be analyzed in this article in comparison to men's views and in interaction with an official political institution. How differently did men and women present themselves towards the député they contacted? Did the lack of certain statutory rights, such as the right to vote for women, have an impact on their identity-based citizenship? How well did the letter-writers know their rights and duties as a citizen, and how did they work with this knowledge? How did the First World War affect their (expressions of these) perceptions?

To answer these questions, I will analyze the passive correspondence of Laurent Bonnevay, who was a member of the Chamber of Deputies (the French Lower House) from 1902 until 1924 and again from 1928 until 1942, after an interlude as a Senator. During his pre-war and wartime mandate (i.e., the period under scrutiny), Bonnevay was a center-right republican for the second constituency of Villefranche-sur-Saône (in the Rhône department), consisting of small rural villages surrounded by high mountains (de Rolland and Clouzet 1902, 2:493). With economic activities centering on the production of grains, potatoes, wine, cattle, woodwork, tiles, and textiles (silk and cotton), the district was largely agrarian but also contained several factories and distilleries. The choice for a rural case helps to verify the supposed paradox of a highly politicised French countryside that nonetheless still heavily relied on feudal patron-client relations (Weber 1976; Agulhon 1979).

Whereas the majority of Bonnevay's preserved incoming correspondence from the period before and after the war consists of letters of thanks from private individuals or letters of congratulations for his (re-)elections, his First World War correspondence is surprisingly more complete. ${ }^{2}$ All wartime questions and follow-up letters are kept in chronological order, with an average of 300 letters a month at its peak (in 1916), which makes his private archives quite exceptional. As a non-mobilised man (because of his age), Bonnevay stayed behind in the capital during the First World War and was accessible there. Nonetheless, his war correspondence testifies to his freedom to return to his district from time to time, to size up the situation where men had left their lands, crafts and trades for the front and war-factories. Because Villefranche-sur-Saône was situated outside the warzone, mobilised constituents could return to their families when on military leave. Furthermore, with its factories and the railway station of Lyon in the vicinity, Bonnevay's district belonged to an important war production and transportation zone. This led inhabitants of Villefranche-sur-Saône to try to get their mobilised male family members posted into one of these safer zones. Because this could not simply be arranged by a clientelist trade-off, they felt compelled to explain their or their family member's deservingness more explicitly than in their pre-war letters, which is what makes Bonnevay's extensive war correspondence particularly interesting to analyze.

Despite his different addresses (one in the suburbs of Lyon, one in the center of Lyon and one in Paris) and his travels between Paris and his constituency, thousands of wartime letters reached him without a problem. Bonnevay was regularly active in parliament in the years 1917-1918 and appears to have resided in his part-time home in Paris for longer periods and/or more frequently during these years. Citizens who then wrote the deputy's address in Lyon on the envelopes were corrected by the mailman, who crossed it out and changed

\footnotetext{
2 Archives Départementales du Rhône (ADR), Fonds Bonnevay, 10J, files 22-28: letters of thanks from private individuals (1897-1957); files 63-64: congratulations for his (re-)elections in the legislative assembly (1902-1936); files 65-76: First World War correspondence (1914-1918).
} 
it to Bonnevay's address in Paris. ${ }^{3}$ At the same time, the député of Villefranche-sur-Saône tried to remain accessible for citizens at the home-front in his constituency. His wartime correspondence files reveal his recurrent visits to Saint-Nizier-d'Azergues, where he resided in Hotel Glattard to enable face-to-face meetings with inhabitants of the surrounding area. Letters written from 1916 to 1918 show that 'ordinary' citizens were aware of this possibility, as several supplicants tried to reach him chez Monsieur Glattard. ${ }^{4}$

Although these examples testify to the députés attempts to remain accessible as well as to the letter-writers' knowledge of his availability and different possible whereabouts, the question remains how well citizens knew what they could rightfully claim. Therefore, the first part of this article examines the different concepts of citizenship, such as (un)enforceable rights, solidarity, duties, and whether or how the letter-writers referred to these notions in their private correspondence with the député. The second part analyzes the impact of the First World War on citizens' knowledge of the rapidly changing policies concerning their social rights and on their perceptions of 'good' citizenship. As political rights (or the lack thereof for women) were clearly not on the letter-writers' minds in these times of crisis, they will not be the focus of this article.

\section{I.1. Concepts and conceptions of social rights and citizens' duties}

As Hassenteufel (1996, 130-31) remarks, those who could rightfully claim help from the welfare state were therefore not automatically recognised as full citizens. In other words, there was not necessarily a causal link between receiving state support and political citizenship. Whereas a so-called secours (a one-off financial aid) replaced individual acts of charity, the vote was a statutory, constitutional right. Still, people's access to social security measures could have had an impact on their 'identity-based' citizenship. More specifically, their feeling of national belonging was likely to be strengthened by their access to benefits from the welfare state. Regarding these benefits, Hassenteufel (1996, 135-36) differentiates between the community-based charity of Bismarckian Germany on the one hand and French republican solidarity on the other. Poor relief based on the republican principle of solidarity can be seen as a debt of the nation towards the poor. It was a 'social duty [...] wider than the traditional concept of justice but more precise, rigorous, and obligatory than charity' (Hayward 1961, 26; Weiss 1983, 56). Although it was vague and therefore still quite noncommittal in its early stages (in the late 1880s), the principle mattered as a 'moral basis' for poor relief outside of the Catholic framework and within a non-clerical republican one (Weiss 1983, 58). Moreover, the concept of solidarity gradually became regulated by law. The requirements that were stipulated for the validation of applications for poor relief were based on the applicants' inability to cover their basic needs through work and disregarded their contribution to society as a rightful claim.

The law of 14 July 1905 on compulsory assistance for the aged, the disabled and the incurably ill was a first important step in making such solidarity legally enforceable; thus, it was turned into a statute. ${ }^{5}$ Although during and after the First World War, such state allowances expanded to preserve 'the right to live' for all French citizens, solidarity remained strictly

\footnotetext{
${ }^{3}$ For example: 'Letter from Mr B. Girard from Grandris (Villefranche-sur-Saône),' November 5, 1918, ADR, Fonds Bonnevay, 10J, file 76.

${ }^{4}$ For example: 'Letter from Mrs C. Petit from Saint-Bonnet-le-Troncy (Villefranche-sur-Saône),' January 1, 1916, idem, file 69/I; 'Letter from Mr N. Rochard from the farming division in Castelginest (Toulouse, Haute-Garonne) but originally from Villefranche-sur-Saône,' October 30, 1918, idem, file 76; 'Letter from widow Arnaud from Saint-Nizier-d'Azergues (Villefranche-sur-Saône),' November 11, 1918, idem.

5 'Loi relative à l'assistance obligatoire aux vieillards, aux infirmes et aux incurables, privés de ressources,' JO. Lois et décrets 37 (July 16, 1905): 4349.
} 
regulated in terms of deservingness throughout the Third Republic (i.e., until after the Second World War). Able-bodied men and women younger than 70 who did not manage to make ends meet still had to count on the kind of poor relief that was not simply enforceable as a civil right. As the right to state support was not as 'universal' as the right to vote was said to be (though solely for male citizens), applicants needed to clarify their 'identity-based' citizenship and how they thought it could validate their claim to this support. Because of the limits and vagueness of the notion of solidarity, which did not completely overlap with statutory citizenship, the difference between perfect (enforceable) and imperfect (unenforceable) rights (such as claims to charity) was likely to be hazy for French men and women. Consequently, deservingness was open to interpretation and negotiation.

Important to note is that the studied letters do not literally refer to either solidarity or citizenship. Still, being on the receiving end of solidarities, many letter-writers did in fact appeal to the notion of the word by referring to the deputy's charitable intérêt, his 'sympathy' or a 'service' towards them. This phraseology suggests that the letter-writers were aware of the unenforceable nature of their request and expected the deputy's help on a more informal level. It should not come as a surprise that a job recommendation was often referred to in terms of charity or benevolence, because the letter-writers realised that they could not claim the absolute right to a job. The same was true for Bonnevay's 'favours' to farmers from his constituency, for whom he had in the pre-war years arranged a military leave, a postponement of their military service, or a posting to a different regiment. However, this did not mean that the applicants considered such requests as any less legitimate. The harvest season was a good reason for a postponement and, given Bonnevay's known efforts or services for people from the valley, his interventions on the farmers' behalf seemed only logical, even though they knew that what they were asking was not enforceable. ${ }^{6}$

The issue of allowances was more complex because, on the one hand, there were laws regulating the payment of pensions to which applicants could claim they had the right. On the other hand, for those who could not appeal to such an allowance on legal grounds, there was still the possibility to apply for a secours (either locally or towards a Minister), and call in the deputy's 'charitable intervention' for it. Even when citizens could make legal claims to a specific financial benefit but found themselves unable to enforce it, they not only tried to convince the député of the legitimacy of their request but also recurred to notions of 'benevolence.' Especially when slow administrations hindered the citizen in obtaining his/ her enforceable rights, a deputy's 'kindness' or 'support' was still the target of appeals.?

Although in many letters (written by men or women) the députés services were often perceived as acts of kindness, we should avoid overinterpretations of rather general phrasings such as thanks for 'votre charitable intérêt.' It was a quite common way of expressing gratitude for the representative's efforts on their behalf, almost as a figure of speech in some cases. As recommended by late nineteenth- and early twentieth-century handbooks on epistolary style (Ducret s.d., 74; Manillier 1884, 16-20; Frère Gabriel-Marie 1908, 215-22), many letterwriters respectfully, but without being overly fawning, focused on the politician's praiseworthy capacities, like his well-known benevolence and the ease with which he would be able to grant the favour. In addition, instead of making a concrete promise that was impossible

\footnotetext{
${ }^{6}$ Some early examples: 'Letter from Mr C. Margand from Oingt (Villefranche-sur-Saône),' June 23, 1906, ADR, Fonds Bonnevay, 10J, file 22; 'Letter from Mr D. Ruy in Tarare (Villefranche-sur-Saône),' August 31, 1908, idem.

7 There were several requests from 1910 for a secours to be granted by the Minister of War to veterans of the 1870-1871-war, e.g. 'Letter from Mr J.-M. Manus from Saint-Forgeux (Villefranche-sur-Saône),' April 19, 1910, idem; 'Letter from Mr J.M.F. Ovise from La Ville (Villefranche-sur-Saône),' May 24, 1910, idem; 'Letter from Mr J. Decurel from Chessy (Villefranche-sur-Saône) on behalf of Mr S. Combes (from the same village),' June 22, 1910, idem.
} 
to keep, these manuals advised to make an indirect promise by expressing how grateful the letter-writer and their family would remain. The choice to frame the deputy's 'service' as a kind gesture thus aligned with this epistolary etiquette of the time, and allowed women to claim the same level of engagement from the politician as men did. Women too could promise their 'devotion' and highlight their relation of debt as the deputy's obligée or even his humble servante. ${ }^{8}$ Although these expressions could not imply the same as men's promises for 'future' or 'eternal' gratitude, servitude and/or devotion, ${ }^{9}$ many female letter-writers seemed convinced that their prayers and wishes for the deputy's good luck carried the same weight as their male counterparts' implicit or explicit support. On a piece of lace-cut paper, decorated with hand-painted flowers, Mrs Bonnouche Rival, for example, wished Bonnevay at the beginning of 1910 a perfectly happy and long life in good health. Even though she referred to her husband joining her in her New Years' wishes, she expressed her gratitude (for the 'great kindness' Bonnevay had shown towards her) solely on her own behalf, confident in the impact of her own words. ${ }^{10}$

Although the combination of men's 'gratitude' with the mere mention of their place of residence could already imply political support for the deputy, some letter-writers expressed their own or their family's support more explicitly. This did not mean that the letters were examples of pure clientelist trade-offs. Bonnevay's correspondents appear to have realised that merely presenting themselves as his constituents was not enough to justify their requests. Whereas a matter of justice could be a legitimisation, because there was legal proof that the applicant had indeed the right to obtain what he/she claimed, a charity case needed further justifications to underline the applicant's deservingness. Remarkably, most of Bonnevay's correspondents had at least an idea of what they wanted or could ask for in their situation. Instead of simply asking for money, they requested the deputy's help in obtaining a breadwinner's replacement income, a retirement pension, elderly benefits, cheap train tickets, a job in a certain sector, a job transfer or a promotion.

In many cases, citizens only contacted the député after having been sent from pillar to post without receiving a satisfying result. Through these unsuccessful attempts, they were educated on how their individual situation failed to link up with statutory rights. However, the letter-writers were not passive subjects of the implications of these policies on their identitybased citizenship. A woman whose husband-breadwinner had to join the army, for example, was convinced that his replacement income was rightfully hers. Nonetheless, Susan Pedersen (1990, 983-86) and Susan Grayzel (2014, 107-8) are right in stating that the allowances granted by the Western European governments to women were strongly based on the dependency of these women on a male breadwinner. Before the war, it was indeed not uncommon for a man whose military service temporarily bereaved his family (wife or parents) of their only breadwinner, to consider the allowance that compensated for his absence as his wages. When a man then took the initiative for obtaining this allowance, it becomes clear that he saw it as his duty to continue to provide for his family's survival.

Such was the case for Jean Blanc, who thanked Bonnevay in March 1908 for his intervention. Blanc was sure that, c'est grâce à vous, que j'ai pu obtenir, ou plutôt que mes parents ont

\footnotetext{
8 For example: 'Letter from widow Dupuis from Les Olmes (Villefranche-sur-Saône),' February 7, 1904, idem; 'Letter from Mother Superior Elisa de St.-Jean from the Asile des Petites Sceurs des Pauvres from Tarare (Villefranchesur-Saône),' December 13, 1910, idem; 'Letter from Mrs M. Chermette from Pontcharra (Villefranche-sur-Saône), November 9, 1918, idem, file 76.

${ }^{9}$ For example: 'Letter from Father Ronzier from Saint-Christophe-la-Montagne (Villefranche-sur-Saône),' March 13, 1906, idem, file 22; 'Letter from Mr P. Subtil from Lyon,' June 18, 1912, idem, file 23.

10 'Letter from Mrs B. Rival from Tarare (Villefranche-sur-Saône),' January 4, 1910, idem, file 22. (It is unclear to what favor she referred.)
} 
pu obtenir l'indemnité journalière. Although at first, he referred to 'his' allowance, he corrected himself immediately thereafter by stating that his parents received it. Nonetheless, his choice of words stressed the fact that it was a compensation for his absence. In addition, his promise 'to stay loyal to the liberal and progressive Republic' upon his return emphasised his agency and not that of his parents. His reference to the Republic indicated his support for Bonnevay's political affiliation (to the so-called progressive republicans of the center-right). ${ }^{11}$

In another pre-war example, from a few years later, Gabriel Salot informed the deputy of having received his letter, announcing the decision of the departmental committee to grant him (Salot) 'the breadwinner's allowance' (l'allocation des soutiens de fammille [sic]). The letter-writer did not know how to express his gratitude for the trouble the député had taken for him. Thanks to Bonnevay's efforts, Salot remarked, his wife and daughter did not have to live in misery. ${ }^{12}$ Both Salot and Blanc promised their continued support for the representative because of his interventions in 'their' allowance cases. Along the same lines, J. Giraud legitimised a new request on 4 December 1912, by referring to the deputy's previous successful intervention, thanks to which his brother had obtained the daily allowance during his military service. Their widowed mother was not literally mentioned as the actual recipient of this aid. ${ }^{13}$

Female letter-writers, on the other hand, most often considered the breadwinner's replacement income as their own. Already in 1910, Elise Barré expressed her 'profound gratitude' towards Bonnevay for his 'kind protection,' thanks to which she had obtained mon secours militaire. Although she thus appears to have linked the success of her request to the good deed of Bonnevay as her patron-protector, she was also convinced that the money was her due; not as mere charity but as her enforceable, statutory right. ${ }^{14}$ This was even more characteristic of letters from wives and mothers of mobilised men during the First World War, who were compelled by the circumstances to be well-informed of their rights and to take care of the formalities to claim their due.

\section{I.2. Impact of the First World War on notions of citizenship}

During France's partial occupation, many députés remained politically active and accessible. The plenary debates were only suspended from August to December 1914. Fabienne Bock (2002, 95-116) records a substantial group of active deputies in 1915 and 1916, with a presence of at least 500 out of 601 representatives taking part in the voting of measures. Some combined their military duty with their parliamentary mandate and were able to inform their colleagues on the reality at the front. In addition, parliamentary committees ensured supervision over the executive power. Many citizens indeed seem to have had a lot of faith in 'their' individual representative and his influence on executive powers. In the case of Bonnevay, citizens' expectations of his role often even exceeded his representative task, yet, instead of merely informing his supplicants about the limits of his authority, Bonnevay tried to meet their expectations as much as possible, if they were in line with the ideal of equality of opportunities. While, through their war correspondence with the député, citizens became more aware of his attachment to this republican ideal, they also learned to frame their individual requests along the lines of such a greater value and what they thought were (or should be) their enforceable rights.

\footnotetext{
11 'Letter from Mr J. Blanc from le Bois-d'Oingt (Villefranche-sur-Saône), written from his regiment in Montbéliard (Doubs),' March 22, 1908, idem.

12 'Letter from Mr G. Salot from Tarare (Villefranche-sur-Saône), written from Lyon,' March 7, 1910, idem.

13 'Letter from Mr J. Giraud from Amplepuis (Villefranche-sur-Saône),' December 4, 1912, idem, file 31.

14 'Letter from Ms E. Barré from ?,' May, 1910, idem, file 22.
} 
Seemingly at odds with this logic, men and women contacted Bonnevay during (the early stages of) the war on the assumption that he would and could send their mobilised family member or themselves to a line in the back, to a war factory in the interior, to the supply services at the railway company in Lyon or home on leave. Others seemed to expect that he would be able to convince the medical examiners to declare them or a family member unfit for military service. Considering the high proportion of farmers and artisans in Bonnevay's district, the large number of such wishes was not surprising, for all manpower could be used in family farms and factories, to keep life sustainable. Nonetheless, in the context of the early months of the war, when parliament was dissolved and preferential treatment for constituents had become less justifiable, such expectations of an individual representative's concrete influence and action may appear out of place. They seem to suggest that rural citizens (still) heavily relied on their patron-client relationship with their député.

Bonnevay was, however, not just a parliamentary representative, but he also continued to represent the canton of Lamure-sur-Azergues on the departmental level as a general councilor. In the latter capacity, he was automatically a member of the cantonal conseil de révision, which decided upon the military recruitment and unfitness of men (Griolet and Vergé 1910, 69). Pre-war letters of thanks make clear that in this combination of capacities, Bonnevay had been an important support for the families of his rural district before. His letters of recommendation for military leaves, postponements of military service (until after harvest time), or declarations of unfitness appear to have been very successful back then. Although the député struggled to (morally) justify such preferential treatment for constituents since the outbreak of war, he saw it as his duty to reply to these requests regardless. Rather than offer a ready-made solution, he educated his correspondents on the actual political situation while suggesting possible steps to take. ${ }^{15}$

The interactive adjustment of citizens' expectations regarding the deputy's role and the enforceable nature of their rights appear clearly in Bonnevay's correspondence with PierreMarie Félix Jacquet. On 27 January 1915, Jacquet, a mobilised laborer at the supply services in Fort Villeurbanne (Lyon), requested the deputy's support for his application for sick leave. At the moment of writing, the man was recovering from an ankle fracture in a temporary convalescent hospital in Saint-Rambert-l'Île-Barbe (close to Lyon). Stressing that he was far from being recovered, as he still walked with difficulty, Jacquet formulated his wish to convalesce at home. Therefore, he needed Bonnevay to write a letter to Dr Chabaud (chief physician at the hospital), encouraging the latter to write a recommendation to the conseil de réforme. The demand for declarations of unfitness was so high that Jacquet thought he should make a difference through 'a certain protection, for the request to be taken into consideration.' Not merely asking for it but clearly counting on the deputy's support, the letter-writer did not shy away from explicitly placing himself under the députés patronage and expecting to be favoured by him.

However, Bonnevay made clear that he could not ask a physician to recommend a soldier to the conseil de réforme, as 'it would run counter to the goal pursued by the rest.' With this vague phrasing, he meant that this action would create an unfair competition, while every applicant should have equal opportunities. Decisions for military leaves and declarations of unfitness should be solely based on the severity of each situation, without any influence of a recommendation. Still, the deputy contacted the Minister of War to be informed about what the man was entitled to. The Minister apparently ensured him that Jacquet had the right to spend his sick leave at home. Even though the letter-writer got what he wanted (because he

\footnotetext{
15 'Correspondances reçues, août-décembre 1914,' idem, file 65 (including the summaries of Bonnevay's draft
} responses on top of each letter). 
had indeed the right to it), Bonnevay made sure to denounce motives that were too clientelist, instead supporting more politicised values. ${ }^{16}$

When the deputy of Villefranche agreed that a certain case was an example of a broader injustice, he involved himself more openly, by interpellating in parliament once plenary sessions were reinstated or by addressing an official written question to the Minister concerned. Such questions for information generally started with a complaint about an unfair situation - as pointed out by correspondents - which could not always lead to direct change. In the case of the so-called Armée d'Orient (the Oriental Expeditionary Force at the Salonica front) in early 1917, the deputy addressed questions to the Minister of War because of a lack of clarity and suspected unfairness concerning the furlough for soldiers at the Salonica front, in comparison to the regulations for those at the Western front. During the debates on this topic, Bonnevay did not refer to an individual case but to a specific regiment that he claimed to know well (i.e., the regiment to which his Beaujolais correspondents belonged), where furlough had only been granted to a small minority. By the month of March, 'the parliament' had already complained several times about this situation, he remarked, yet none of the Ministers of War (rapidly succeeding each other) had been able to grant the wishes that had been formulated multiple times in the plenary debates, 'in the spirit of justice.' This 'spirit' also marked the rhetoric in the letters from the Salonica soldiers, who offered Bonnevay inspiration for his speeches. ${ }^{17}$

Even though the misery of these soldiers, as well as of those left behind at the home-front spoke for itself, Bonnevay's supplicants nonetheless often added another layer of legitimisation. The letter-writers commonly reinforced their argument of misery either through a very humble or even subservient self-presentation, or rather through a more assertive protest against the unfairness of the circumstances. Whereas the more subservient letter-writers particularly recognised Bonnevay's expertise, they thus counted on his knowledge and power to enforce change, the assertive letter-writers generally displayed their knowledge of a specific policy that affected them directly; hence, they educated the deputy from their side.

It seems typical for citizens addressing authorities to use a trial-and-error method including diverse rhetorical elements to increase their chances of success, which was not an exclusive feature of letters to deputies in the French Third Republic. In his analysis of English pauper letters to parish officers in the districts of Essex between 1800 and 1834, Thomas Sokoll $(2000,42-43 ; 2006,102)$ remarks that defensive (modest, humble, 'apologetic phraseology and deferential') rhetoric and what he calls offensive rhetoric (protest highlighting the unfairness of the situation and their conviction that their claims were legitimate) were typically combined. Rarely did Bonnevay receive a letter that was truly offensive, in the sense of containing a personal attack. However, it does seem that the First World War brought about more assertiveness among the letter-writers (with an increase in female assertiveness), although most of them, similar to Sokoll's cases, combined their 'protest' with the common deferential rhetorical aspects referred to in the first part of this article.

For example, factory-weaver Alphonse Lacombe used several tactics in one letter to Bonnevay, which he wrote only a few weeks after the beginning of the war. First, Lacombe

\footnotetext{
16 'Letter from Mr P.-M. F. Jacquet from his place of recovery in Saint-Rambert-l'île-Barbe (close to Lyon),' January 27, 1915, idem, file 66.

17 'Letter from J. Delafay from Bagnols (Villefranche-sur-Saône),' and 'Petition from a group of families of soldiers of the Armée d'Orient from the Haut-Beaujolais,' and 'Letter from B. Michaud a.o. on behalf of families from Alix (Villefranche-sur-Saône), January 20, 1917, idem, file 71/I; 'Question écrite n 13844,' JO Débats Chambre, January 23, 1917, 147; 'Letter from corporal H. Pouly (recovering in Grandris, Villefranche-sur-Saône),' January 23, 1917, ADR, Fonds Bonnevay, 10J, file 71/I; 'Réponse à question n 13844,' JO Débats Chambre, February 8, 1917, 338; idem, March 30, 1917, 977.
} 
began his letter, which was filled with spelling errors, by requesting a deserved grand Serviçe [sic]. Paradoxically, however, although he counted on the deputy's unenforceable 'good heart' and 'high influence', he needed Bonnevay's help to assert what he called his 'civil rights.' In fact, what he really needed was a correct execution of the law; at least that was how he saw it. Secondly, to ensure these rights, he tried to prove that he was a good citizen. Therefore, he stressed the importance of the allowance he claimed to have only applied for out of necessity, for the survival of his large family. In this context, he mentioned having 11 children of whom only five were still alive, and only the eldest was the family's breadwinner, yet the latter would not be able to provide for his family anymore once he was mobilised. Consequently, the prospect of 'great misery' that was out of Lacombe's control drove him towards his application for a breadwinner's replacement income. Describing it as an allocation journalière que la loi accorde au [sic] familles nécessiteuses, he highlighted that a destitute situation like his legally justified his application. Moreover, by showing that he knew to whom he should address his plea, he proved himself an enterprising citizen who knew what to do to keep his family alive. Although Lacombe had the municipal council's unanimous approval, or so he claimed, his engagement was counteracted by the gendarmerie whose investigation had been influenced by 'people of little value.' Apparently, he suspected those who had been interviewed to have spoken badly of him, which he had tried to invalidate by adding his clean record to his application, as proof of his good citizenship. It was the mayor who had advised Lacombe to turn to Bonnevay for support and who certified Lacombe's signature. In his response, the député assured the man that his case would be impartially examined in Thizy (i.e., on the cantonal level). ${ }^{18}$

Given Bonnevay's 'kind soul' that was 'legendary in our arrondissement', gardener Alfred Favre was also convinced that he could legitimately count on Bonnevay's help. Just like Lacombe, Favre expected support for his application of the allowance he felt he had the right to claim in his capacity as a father of a large family, facing pure misery during the war. The focus on his misery and thus on the necessity of the allowance to survive, in combination with an appeal to the deputy's kind soul, was not an exceptional legitimisation of a request for an allowance. Especially in cases of extreme misery, the only way to survive seems to have been through the kind action of a deputy, as a counter to the slowness, passivity or even the suspected ill will of certain administrations. Therefore, the letter-writers' chosen phrasings make it seem as if these citizens were entirely dependent on the deputy's goodwill to obtain an allowance, instead of being able to claim it as their legal right.

How should we interpret such common phraseology that, at least at first sight, appears to have reduced the active letter-writer to a passive subject to misery and regulations beyond his/her control? In the case of Alfred Favre who (among many others) contacted the deputy only after he had hit rock bottom, the letter-writer had already taken action to solve his financial problems himself, before turning to Bonnevay in January 1915. As a father of a large family, Favre had tried to keep his head above the water after the mobilisation of one of his sons, who used to be the family's main breadwinner. When Favre still had a job himself, he had been able to put some money aside; he had not asked for an allowance, but since his employer had to close his enterprise when being called to arms, the man found himself to be 'vegetating.' Nonetheless, he had tried to keep working to earn some money, but he had only been able to take on temporary jobs of one or two days, here and there. At the advice of his neighbours, Favre had already contacted the municipality for financial help, after having used up his savings first. Only because he had not heard back from them, did he write to Bonnevay,

\footnotetext{
18 'Letter from Mr A. Lacombe from Pont-Trambouze (Villefranche-sur-Saône),' August 18, 1914, ADR, Fonds Bonnevay, 10J, file 65 (containing a scribble of Bonnevay's draft response from August 25).
} 
hoping that he could help him obtain an allowance. Favre stressed that he was driven by pure necessity, because his youngest child was ill, he had no job or money left, they had no coal to warm themselves and at least one day a week, he was unable to put bread on the table. If the winter were over, he would not have bothered asking for help, he claimed. The letter-writer thus showed himself an independent citizen, who had tried to manage himself, but who, in the worst circumstances, had to appeal for state support to ensure his and his family's survival. In his response, the député explained which steps the man could take to appeal after a possible rejection.

Important to note here is that, although the deputy's 'kind soul' was what Favre counted on in the end (which sounds very passive), the man had proven himself to be very enterprising in his search for a solution to his problems. Moreover, his detailed explanation of his situation shows that he was well aware of the regulations that required true deservingness of citizens before they could rightfully claim an allowance to survive. ${ }^{19}$ Many non-mobilised people like Favre were suffering at the home-front, but financial compensation for their losses was subject to very strict rules. Even though this might not seem very surprising, it is different from the situation in Britain, for example, where all families were compensated for a mobilised soldier (Pedersen 1990, 983-86; Grayzel 2014, 107-8).

To cover the bare necessities for the survival of the French soldier's family during the war, the breadwinner's replacement income amounted to $1.25 \mathrm{~F}$ per day (for his wife or parents), raised by $0.5 \mathrm{~F}$ per day for each child under the soldier's care that was below the age of 16 . This was, however, only reserved for those who really needed the money to survive. ${ }^{20}$ If the soldier's wife had a job or if the man was mobilised in a war factory where he received an income to sustain his family, their allowance was denied or withdrawn. Although these amounts and conditions were in place since the beginning of the war, the so-called Commission Supérieure, the Higher Committee of Appeal, was only created at the beginning of 1915 in response to the growing demand for allowances and complaints about the unfair applications of the law on the local level. Especially between town and countryside, there were different interpretations, often to the detriment of poor farmers and merchants. ${ }^{21}$ Although no concrete link can be found between the letters sent to Bonnevay in 1914 and the Minister of the Interior's official denunciation of such practices, it is highly likely that the Minister's creation of the Higher Committee of Appeal was an attempt to correct the flaws that he had heard in complaints.

Encouraged by the citizens' personal requests and his initial powerlessness to help them at the outbreak of war, Bonnevay enlarged his field of concrete action by taking part in this committee. In the first instance, it was up to the cantonal committee of the family's hometown to decide upon the deservingness of each citizen, under the supervision of the vice-prefect or the prefect himself who had to sign the form. If either the (vice-)prefect or the concerned party wished to challenge the cantonal committee's decision, the case had to be taken to said Commission Supérieure. Bonnevay thus made sure to belong to an executive institution that mediated between the local (cantonal) and the national level. There, he could exert influence on the correct execution of war policies, whereas in old and new parliamentary committees, he could contribute to their creation. Although Bonnevay did not seem to have been allowed

\footnotetext{
19 'Letter from Mr A. Favre from Pontcharra-sur-Turdine (Villefranche-sur-Saône),' January 3, 1915, idem, file 66.

20 'Loi tendant à accorder, pendant la durée de la guerre, des allocations aux familles nécessiteuses dont le soutien serait appelé ou rappelé sous les drapeaux,' JO. Lois et décrets 46 (August 6, 1914): 7127.

21 Impressions Chambre 437/art. 15, (December 22, 1914): 20-22 and 36-37; and the subsequent Ministerial Order by Louis Malvy (Minister of the Interior): Bulletin officiel du Ministère de l'Intérieur, Paris: Dupont, (January 1, 1915): 15-16.
} 
to vote when the Higher Committee treated cases from citizens of the Rhône department, ${ }^{22}$ most of his passive correspondence concerning the daily allowance came from people from this department. To them, he was an important source of information on how to proceed and what to expect, especially because not all citizens were (immediately) aware of their right to appeal. ${ }^{23}$ On several occasions, the deputy had to encourage them to do so as a last resort while sharing his view on the possible outcome of their case. ${ }^{24}$ Whereas these written interactions thus encouraged the deputy to expand his representative role, they led citizens to elaborate on their (knowledge of their) deservingness.

Men and women who decided to write a letter to Bonnevay did not primarily aim to clarify their duties connected to their citizenship. These were much more implied than the rights they highlighted to be able to benefit from the welfare state. Therefore, it is quite impossible to consider the word devoir as a keyword in the search for the letter-writers' views on their duties as French citizens. However, in their attempts to obtain what they thought were their rights - referred to as droits, in the context of (in)justice(s) - it was not exceptional for correspondents to implicitly construct their image as a good Frenchman/-woman, hence alluding to their knowledge and perception of what a good citizen was supposed to be.

For example, in January 1918, Marie Dupeuble wrote to the deputy that her application for a military allowance had been rejected a second time because she was not perceived as destitute. As a counterargument, she compared herself to women who paid more taxes than she did, and who received a military allowance, nonetheless. She wondered if they had done better by not paying their taxes during their husband's mobilisation. In other words, Dupeuble denounced a blatant injustice: she felt punished for doing her civil duties (paying taxes) and thereby depriving herself of vital necessities while not being able to pay the bills anymore. This constituted her main line of argument: she needed this allowance, which she felt entitled to receive, not only because her husband was at the front, or because others received it too, but even more so because she could simply not survive without it. Unsurprisingly, this was a quite common justification.

Furthermore, Dupeuble supported her motivation through explanations that showed her high awareness of the war policies affecting her financial situation. As a merchant of grains, she saw her business go to ruin by the requisitions of oats. Moreover, in her region, the sale of other grains had stopped as well, whereas the sale of other small goods did not suffice to keep commerce open. Therefore, Dupeuble expected Bonnevay to help her formulate her demand once again. 'Some people', whom she did not specify, had warned her, however, that it would be difficult for her to receive the allowance, given 'their' (her husband's and her) political ideas. Even though she claimed that she did not want to believe that such favouritism could be the reason for the rejections, she decided to bring it up, nonetheless. This gave her the opportunity to stress that indeed all her male family members adhered the same ideology as Bonnevay did and belonged to his constituency. The ideological support of her family members to Bonnevay was even the sole reason why she dared to contact the deputy, as it was the only way to be sure that he would do anything he could in her favour, she thought. Dupeuble

22 'Draft response from L. Bonnevay to Mr J. Proton de la Chapelle from Lyon,' November 16, 1917, ADR, Fonds Bonnevay, 10J, file 74/I.

${ }^{23}$ In his second response, Bonnevay informed Proton de la Chapelle of the rejection of his protégé's appeal by the Higher Committee, January 3, 1918, idem.

${ }^{24}$ For example: 'Letter from the sergeant-secretary of a territorial commandment (and formerly a notary from Thizy) on behalf of comrade M. Poizat,' January 24, 1915, idem, file 66. The allowance of his comrade's wife had been withdrawn for unknown reasons. In his draft response, scribbled on top of this letter, Bonnevay explained that Mrs Poizat should take the case to the Higher Committee, which would probably restore her allowance. 
thus promoted her request as a joint battle against the injustice embodied by their shared adversaries. $^{25}$

Aside from this clientelist expression, the example of Dupeuble also displays high political awareness and knowledge on the level of national politics (cf. the matter of requisitions for which Bonnevay had been the rapporteur in parliament ${ }^{26}$ as well as on the level of local politics (cf. the unfair distribution of allowances). She had proven to be a well-informed citizen, who could not be accused of passivity for asking the deputy for help. Petitioning him simply looked like the only way out, after what seems to have been a long struggle. Waiting and trying to deal with such struggles on their own first was especially typical during the years 1916-1918. As the war progressed, the financial situation of families at home worsened, and the need for allowances grew inevitably. Several women waited to act until the situation became entirely unbearable, the daily military allowance was the only outcome and the député their last resort.

Mrs A. Alamercery from Trévoux (in the Ain department, but close to Lyon, where Bonnevay lived) already received such a compensation but requested the deputy's help in January 1916 in obtaining 'the raise foreseen for my daughter.' Through her choice of words, she made it clear that there should be no doubt about her deservingness of this child support. Her husband belonged to the first draft of soldiers, mobilised almost one-and-a-half years prior to her letter to Bonnevay. If she was so sure of her case, why did she ask for his help so late? Alamercery's decision to contact the deputy mainly reflected the failure of her request on the local level. As in many cases, her late call for help was not a matter of passivity. She had already submitted her application for the raise of her allowance to the cantonal committee of Trévoux. There, they had rejected her demand, because her wages were 'sufficient.' Alamercery considered this to be a flawed argument, for the work she did required 'the greatest sacrifices.' She claimed to render 'indispensable services to the community, like transport of dispatches, prisoners, tobacco, garbage and night soil', despite the mobilisation of her husband since the beginning of the war. She ensured that she would not ask for the raise if she could continue without it. ${ }^{27}$ This way, she tapped into the official rhetoric of the law that regulated the 'allowances for families in need,' as well as the decree and circular letter of the Minister of the Interior to the departments' prefects that fixed the conditions at the beginning of the war. ${ }^{28}$

Because of the emphasis on her deservingness, Alamercery's letter was entirely in accordance with these official regulations and their phraseology. Still, this does not mean that she had read the law, decree or circular letter. It was widely known that only the poorest members of society could make claims to the financial support meant to replace the mobilised breadwinner's wages. Moreover, it was common sense for supplicants to highlight their poverty after the rejection of their demand. Letter-writers like Alamercery took pride in their honesty and endurance, stressing that they only asked for the money as a last resort because they really needed it to survive. (This aligned with men's letters, cf. Lacombe's and Favre's rhetoric.) Because of this fair attitude, they considered themselves good French citizens. This was especially true for Alamercery, who had actively contributed to society and made sacrifices for the community. Just like Dupeuble, however, she felt punished for doing her citizen's duty: if she had given up on her community jobs, it would have been easier for her to claim the raise.

\footnotetext{
25 'Letter from Mrs M. Dupeuble from Pontcharra-sur-Turdine (Villefranche-sur-Saône),' January 8, 1918, idem, file $74 /$ I.

26 'Annexe au procès-verbal de la séance du 27 juillet 1917,' Impressions Sénat 260: 1-8.

27 'Letter from Mrs A. Alamercery from Trévoux (Ain),' January 2, 1916, ADR, Fonds Bonnevay, 10J, file 69/I.

28 JO. Lois et décrets 46 (August 6, 1914): 7127-7138.
} 
This was not possible, because life was simply too expensive. When she had explained her situation to the local Committee of Appeal in Trévoux, they had threatened to withdraw the allowance she already received if she would not drop the case, while she knew very well that her daughter met the legal requirements for the raise she requested. ${ }^{29}$

These are just a few examples of the many letters revealing an important field of tension. French citizens attempted to fulfil a paradoxical duty by, on the one hand, trying to manage themselves in difficult situations (showing courage, enduring misery, and suffering from it), and, on the other hand, knowing when it was time to take action as well as from whom they could seek help in such miserable circumstances. This explains the seemingly late requests, or, in other words, the ubiquitous gap between the citizens' cry for help and the event that had put them in their destitute situation. Hence, not all belated requests should be attributed to a lack of knowledge. On the contrary, the gap could even prove the citizens' knowledge of the important turning point, when their claimed right became enforceable, that is, when it was no longer possible to ensure their own and their family's survival without help. Thus, their letters reflect what they considered as the momentum and the requirements for claiming their universal right to survive.

Regarding the overall nature of the correspondence, citizens still expected personal help and advice from their député-protector in their usually very individual cases; the First World War was not necessarily a huge turning point in these actions. References to Bonnevay's great influence, great service, kindness, protection, and favours, for which they compensated with their devotion, were still an important part of their written interactions. However, 'ordinary' men and women learned to mask the personal nature of their request by adding references to matters of greater importance, comparing their situation to that of other citizens, and contextualising it within the framework of their social-civil rights, the state's responsibilities and its 'republican' value of equality of opportunities. Whereas Bonnevay made sure to educate his early wartime correspondents on this value, the letter-writers in their turn educated the député on the effectiveness and fairness of the social policies in the field. Encouraged by these interactions, Bonnevay decided to take part in wartime committees on the local executive level and on the national representative level. In sum, both the letter-writers' identitybased social citizenship and the députếs multifaceted representative role were negotiated interactively. Meanwhile, the 'republican project' itself was up for debate. Some letter-writers seem to have framed their commitments to the Republic as a reward for Bonnevay's services; hence, they tapped into both clientelist and political justifications of their claims to social rights. Moreover, these claims can be considered successful, not necessarily because they achieved the desired result, but definitely with regard to Bonnevay's consistent responsiveness, as testified to by his draft replies (scribbled on top of the great majority of letters, from men and women alike).

\section{Conclusion}

Taking the distinction made by Patrick Hassenteufel between statutory and identity-based citizenship as a starting point, this article analyzed expressions of the latter citizenship in early twentieth-century France. More specifically, this article focused on how 'ordinary' men and women from a rural area in the Rhône department perceived their place in French republican society shortly before and during the First World War. The war years specifically were a time when (claims to) social policies were continuously renegotiated, in relation to men and women's commitment to the Republic. Whether or not they had political voting rights,

29 'Letter from Mrs A. Alamercery from Trévoux (Ain),' January 8, 1916, ADR, Fonds Bonnevay, 10J, file 69/I. 
'ordinary' citizens took part in these negotiation processes, yet in an informal way, through written communication with a parliamentary representative. Men and women who shared the same social background used similar rhetorical tactics in their requests for help, support or a favour. Though reminiscent of the image of a clientelist rural France at first sight, the quite common Third Republican practice of writing letters to députés was not characterised by mere trade-offs. Instead, these written exchanges were increasingly revealing of how the letter-writers (re)imagined the concepts attached to their citizenship.

Although they did not literally use the word citoyen(neté) in their letters, Bonnevay's correspondents explored different facets of the notion and applied it to their situation. Rhetorically, they turned their unenforceable right to poor relief into their enforceable civil right to survive, which required a certain level of political awareness and knowledge to be convincing. Citizens had to show courage in times of hardship, which they were supposed to try to manage on their own, while they were also expected to appeal in time to their statutory right to survive. Thus, political awareness and knowledge played an important role in connecting (Hassenteufel's interpretation of) statutory and identity-based citizenship. Seeing this was the case, it could be argued that the context of war caused many 'ordinary' citizens to adopt a more 'political' attitude. This also applied to women, whose political knowledge and assertiveness arose in their clarifications of the duties they had fulfilled on the statutory level (abiding by the law and knowing what they could legally claim) and/or on the identity-based level (behaving like a 'good' French subject who worked hard and endured misery without complaining). This latter duty was a vague and universal one, to which both voters and nonvoters could appeal. Similarly, the epistolary stock phrases of the time were vague enough in their promises of gratitude to be applicable in women's requests too, even though women could not promise their vote in return for the députés service or favour. Whereas men made up the majority of the letter-writers, the importance of female engagement grew during the First World War, from a small into a significant minority that could not be ignored. Wives and mothers of mobilised men were now the ones to take care of the red tape to get the support they and their families needed. As a last resort against perceived injustices on (or inertia of) other political levels, their letters not rarely found a responsive deputy on the other end.

The possibility of interacting with a parliamentary representative and even having a certain influence on how he fulfilled his role may explain why Bonnevay's female correspondents did not stand on the barricades for voting rights, not even after the war was over (cf. files 23-25 from the same archive). Although this case study is too limited to make broader claims about French women's (perceptions of their) incomplete statutory citizenship, it hopes to encourage future research into interactive sources that may further contribute to our understanding of the paradoxical dynamics of French Third Republican political culture. By analyzing a larger corpus of letters (including the interwar correspondence of four députés), my dissertation (Lauwers 2019) explores these dynamics in greater detail and a broader context.

\section{Acknowledgements}

My research for this article was sponsored by a PhD project grant, called BOF (Bijzonder Onderzoeksfonds) at the University of Antwerp (2014-2018). At the time of reworking parts of this research into this article for Redescriptions, I had already joined the CALLIOPE team, which has been funded by Josephine Hoegaerts' ERC starting grant at the University of Helsinki's Department of Cultures (2019-till date). I would like to thank her, as well as Marnix Beyen (PhD supervisor) and Henk de Smaele (both from the University of Antwerp) for their feedback on earlier drafts. Furthermore, I am very grateful for the insightful comments from Redescriptions' anonymous reviewers. Lastly, my gratitude also goes out to Marlene Broemer of the University of Helsinki's Language Centre for careful proofreading of my manuscript. 


\section{Competing Interests}

The author has no competing interests to declare.

\section{References}

Agulhon, Maurice. 1979. La République au village. Les populations du Var de la Révolution à la IIe République. Paris: Seuil.

Bard, Christine. 2001. Les Femmes dans la société française au XXe siècle. Paris: Colin.

Beyen, Marnix. 2014. 'Clientelism and Politicization. Direct Interactions between Deputies and 'Ordinary Citizens' in France, ca. 1890-ca. 1940.' Tidsskrift for Historie 4(8): 17-32.

-_-. 2020. 'Informing the Politician: Politics in Parisian Citizens' Letters to Their Députés, 1900-1914.' Journal of Modern European History 18(3): 249-254. DOI: https://doi. org/10.1177/1611894420927218

Bock, Fabienne. 2002. Un parlementarisme de guerre, 1914-1919. Paris: Belin.

Ducret, Étienne. Le Secrétaire pour tous. Correspondance familiale, lettres d'affaires et de commerce, circulaires, pétitions, requêtes, formulaire des actes sous seing privé, etc. Paris: A.-L. Guyot, s.d. https://gallica.bnf.fr/ark:/12148/bpt6k887612f?rk=21459;2.

Frère Gabriel-Marie, F. G.-M. 1908. Manuel de politesse à l'usage de la jeunesse: savoir-vivre, savoir-parler, savoir-écrire, savoir-travailler.Tours/Paris: A. Mame and son (eds. in Tours), and widow C. Poussielgue (ed. in Paris). https://gallica.bnf.fr/ark:/12148/bpt6k5489207j/.

Grayzel, Susan R. 2014. 'Men and Women at Home.' In Cambridge History of the First World War, edited by Jay Winter, 96-120. 3: Civil Society 5. Cambridge: Cambridge University Press. DOI: https://doi.org/10.1017/CHO9780511675683.008

Griolet, Gaston, and Charles Vergé, eds. 1910. Dalloz. Jurisprudence Générale. Recueil périodique et critique de jurisprudence, de législation et de doctrine en matière civile, commerciale, criminelle, administrative et de droit public. Paris: Bureau de la Jurisprudence Générale. https://gallica.bnf.fr/ark:/12148/bpt6k5775642k.

Hassenteufel, Patrick. 1996. 'L'État-Providence ou les métamorphoses de la citoyenneté.' L'Année sociologique, Nation, nationalisme, citoyenneté 46(1): 127-149.

Hayward, J. E. S. 1961. 'The Official Social Philosophy of the French Third Republic: Léon Bourgeois and Solidarism.' International Review of Social History 6(1): 19-48. DOI: https://doi. org/10.1017/S0020859000001759

Lauwers, Karen. 2019. 'Negotiating the Republic. Direct Interactions between Unorganized Citizens and MPs in France, ca.1900-1930s.' Unpublished PhD-thesis, Antwerp: University of Antwerp.

Manillier, A. 1884. Le Secrétaire pratique, nouveau guide pour écrire lettres, pétitions, avec des modèles d'actes sous seings privés, baux, congés, etc. Bibliothèque des salons. Paris: Librairie de Jules Taride. https://gallica.bnf.fr/ark:/12148/bpt6k11756674/f1.

Monier, Frédéric. 2007. La politique des plaintes. Clientélisme et demandes sociales dans le Vaucluse d'Édouard Daladier (1890-1940). Paris: La Boutique de l'Histoire

Pedersen, Susan. 1990. 'Gender, Welfare, and Citizenship in Britain during the Great War.' The American Historical Review 95(4): 983-1006. DOI: https://doi.org/10.2307/2163475

Prost, Antoine. 1997. 'Les monuments aux morts. Culte républicain? Culte civique? Culte patriotique?' In Les Lieux de Mémoire. La République, La Nation, Les France, edited by Pierre Nora, 199-223. La République. Paris: Gallimard.

Rolland, E. de, and Denys Clouzet. 1902. Dictionnaire illustré des communes du département du Rhône. Vol. 2. Lyon: C. Dizain/A. Storck \& Cie. http://gallica.bnf.fr/ark:/12148/ bpt6k5820284v.r.

Rosanvallon, Pierre. 1992. Le sacre du citoyen. Histoire du suffrage universel en France. Bibliothèque des histoires 2. Paris: Gallimard. 
Sokoll, Thomas. 2000. 'Negotiating a Living: Essex Pauper Letters from London, 18001834.' International Review of Social History 45: 19-46. DOI: https://doi.org/10.1017/ S0020859000115275

---. 2006. 'Writing for Relief: Rhetoric in English Pauper Letters, 1800-1834.' In Being Poor in Modern Europe. Historical Perspectives. 1800-1940, edited by Andreas Gestrich, Steven King, and Lutz Raphael, 91-111. Bern: Peter Lang.

Weber, Eugen. 1976. Peasants into Frenchmen. The Modernization of Rural France, 1870-1914. Stanford, California: Stanford University Press.

Weiss, John H. 1983. 'Origins of the French Welfare State. Poor Relief in the Third Republic, 1871-1914.' French Historical Studies 13(1): 47-78. DOI: https://doi.org/10.2307/286593

Zancarini-Fournel, Michelle. 2005. Histoire des femmes en France, XIXe-XXe siècle. Rennes: Presses Universitaires de Rennes. DOI: https://doi.org/10.14375/NP.9782753501980

How to cite this article: Lauwers, Karen. 2021. "Negotiating French Social Citizenship in Early Twentieth-Century Letters to a Representative for the Rhône Department." Redescriptions: Political Thought, Conceptual History and Feminist Theory 24(1): 42-59. DOI: https://doi. org/10.33134/rds.325

Submitted: 02 June $2020 \quad$ Accepted: 29 April $2021 \quad$ Published: 22 July 2021

Copyright: (c) 2021 The Author(s). This is an open-access article distributed under the terms of the Creative Commons Attribution 4.0 International License (CC-BY 4.0), which permits unrestricted use, distribution, and reproduction in any medium, provided the original author and source are credited. See http://creativecommons.org/licenses/by/4.0/.

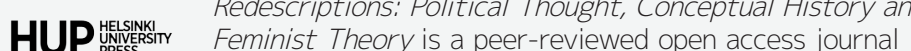
published by Helsinki University Press. 